\title{
Sleep cycle studies in babies of undernourished mothers
}

\author{
V P BHATIA, G P KATIYAR, K N AGARWAL, T K DAS, AND P K DEY \\ Department of Paediatrics, and Department of Physiology, Institute of Medical Sciences, \\ Banaras Hindu University, Varanasi, India
}

SUMMARY Polygraphic sleep cycle studies-comprising simultaneous recording of electroencephalogram (EEG), electrocardiogram (ECG), electro-oculogram (ECOG), phasic body activity, and respiration-were performed on 19 term newborn babies born to severely undernourished mothers, and results compared with 19 healthy newborn babies. The sleep cycle in babies of undernourished mothers showed disorganisation during active rapid eye movement (REM) sleep and quiet nonrapid eye movement (NREM) sleep. The sleep disorganisation was more pronounced during quiet NREM sleep when frequent phasic activity and ocular movements were registered, thereby leading to a significant increase in the content of intermediate sleep. Furthermore, the duration of total sleep cycle and its components, active REM and quiet NREM sleep, were significantly shortened.

Early nutritional deprivation in animals leads to a decrease in the number and size of brain cells, deficient dendritic arborisation, and to alterations in the reticular formation. Furthermore, the content of neurohumoral agents-namely, 5-hydroxytryptamine, acetylcholine, and gamma-amino-butyric acid (GABA) -is also greatly altered. ${ }^{1-5}$ However, the nutritional demands of the fetus during the early stages of gestation are so small that maternal undernutrition has no limiting effect on the growth and maturation of the central nervous system. ${ }^{6}$ The early maturing reflexes and neuromotor features are therefore less likely to be affected. As the neuromotor behaviour and reflex pattern in the newly born are mainly subcortical in origin, the conventional neuromotor evaluation may not show changes in the various regions of the neocortex.

Some investigators have shown that bioelectric brain activity, sleep cycle, and various other electroencephalographic patterns make their appearance and mature at a constant rate in accordance with conceptional age, and are unaffected by low birthweight. ${ }^{7-10}$ Polygraphic study is therefore a sensitive index for evaluating deficits in maturity and

\footnotetext{
Department of Paediatrics, Banaras Hindu University K N AGARWAL, professor of paediatrics V P BHATIA, senior resident paediatrician G P KATIYAR, reader in paediatrics T K DAS, research fellow in physiology P K DEY, professor of physiology
}

organisation during intrauterine growth. In the present study polygraphic recordings were used to evaluate the pattern of sleep cycle in babies suffering from severe intrauterine nutritional deprivation.

\section{Material and methods}

Subjects. A sample was taken of 19 newborn babies of severely undernourished mothers, who had haemoglobin levels $<8 \mathrm{~g} / \mathrm{dl}$ and serum albumin levels $<25 \mathrm{~g} / 1$ (mean $\pm \mathrm{SE} ; 5 \cdot 5 \pm 0 \cdot 19 \mathrm{~g} / \mathrm{dl}$ and $17 \cdot 2 \pm 0.96 \mathrm{~g} / \mathrm{l}$ respectively), and weights $<$ the 25 th centile of that expected for height $(40 \cdot 8 \pm$ $0.89 \mathrm{~kg}$ ). An equal number of healthy newborn babies were chosen as controls from mothers who had had regular antenatal care, and haemoglobin $>$ $1.1 \mathrm{~g} / \mathrm{dl}(12.6 \pm 0.29)$ and albumin $>35 \mathrm{~g} / \mathrm{l}$ $(36 \cdot 1 \pm 0 \cdot 77)$. These mothers had weights above $50.0 \mathrm{~kg}(54.9 \pm 1.35)$ and heights above $150.0 \mathrm{~cm}$ $(155 \cdot 1 \pm 0 \cdot 97)$. The mothers in both groups had uncomplicated antenatal and obstetrical history, and knew the exact dates of their last menstrual periods.

Only term newborn babies with gestations of $280 \pm 2$ days were studied. These babies did not suffer from any birth injury or anoxia and had remained in hospital for a normal period of time.

Methods. The following parameters were recorded simultaneously. These comprised the polygraphic 
studies. (1) electroencephalogram (EEG), 8 channels; (2) electrocardiogram (ECG); (3) electro-oculogram (ECOG); (4) respiratory patterns; (5) phasic body activity, using observation code.

Bipolar EEG recordings were made in a 16channel polygraph machine (Kaizer), using $\mathrm{Ag}-\mathrm{AgCl}$ polarised disc electrodes. Paper speed was $15 \mathrm{~mm} /$ second, time constant was $0 \cdot 1$ second, and high frequency cut filter was used. Electrode resistance was kept $<10 \mathrm{k}$ ohms.

ECG was recorded using lead I. ECOG was recorded using 2 electrodes and by visual observations. Respiration was observed continuously during the recording and 3 types of patterns were found-namely, regular, irregular, and periodic/ apnoeic.

A continuous record of body movements was made with precise discrimination using the following observation code: Grade I, slight movement/ movement of one component of an extremity. Grade II, moderate grade of movements, head rotation not crossing midline. Grade III, gross, high amplitude movements, rolling over, cry. Each recording lasted between $2 \frac{1}{2}$ and 3 hours.
Sleep cycle

Active REM sleep. If 4 of the following criteria were present the baby was said to be having active REM sleep: (1) low voltage-high frequency EEG, (2) frequent phasic activity, (3) irregular respiration, (4) irregular heart rate, (5) presence of rapid eye movements.

Quiet NREM sleep. If 4 of the following criteria were present the baby was said to be having quiet NREM sleep: (1) high voltage, low frequency EEG, or 'trace-alternant EEG', (2) absence of phasic body activity, (3) regular respiration, (4) regular heart rate, (5) absence of ocular movements.

Sleep which could not be designated to either state was categorised as 'intermediate'.

Blood samples were collected from the mothers before delivery to estimate haemoglobin, total proteins, and albumin. ${ }^{11}$ Wet placental weight was recorded, after trimming the membranes to the margin and cutting the cord at insertion.

\section{Results}

Babies born to undernourished mothers had severe
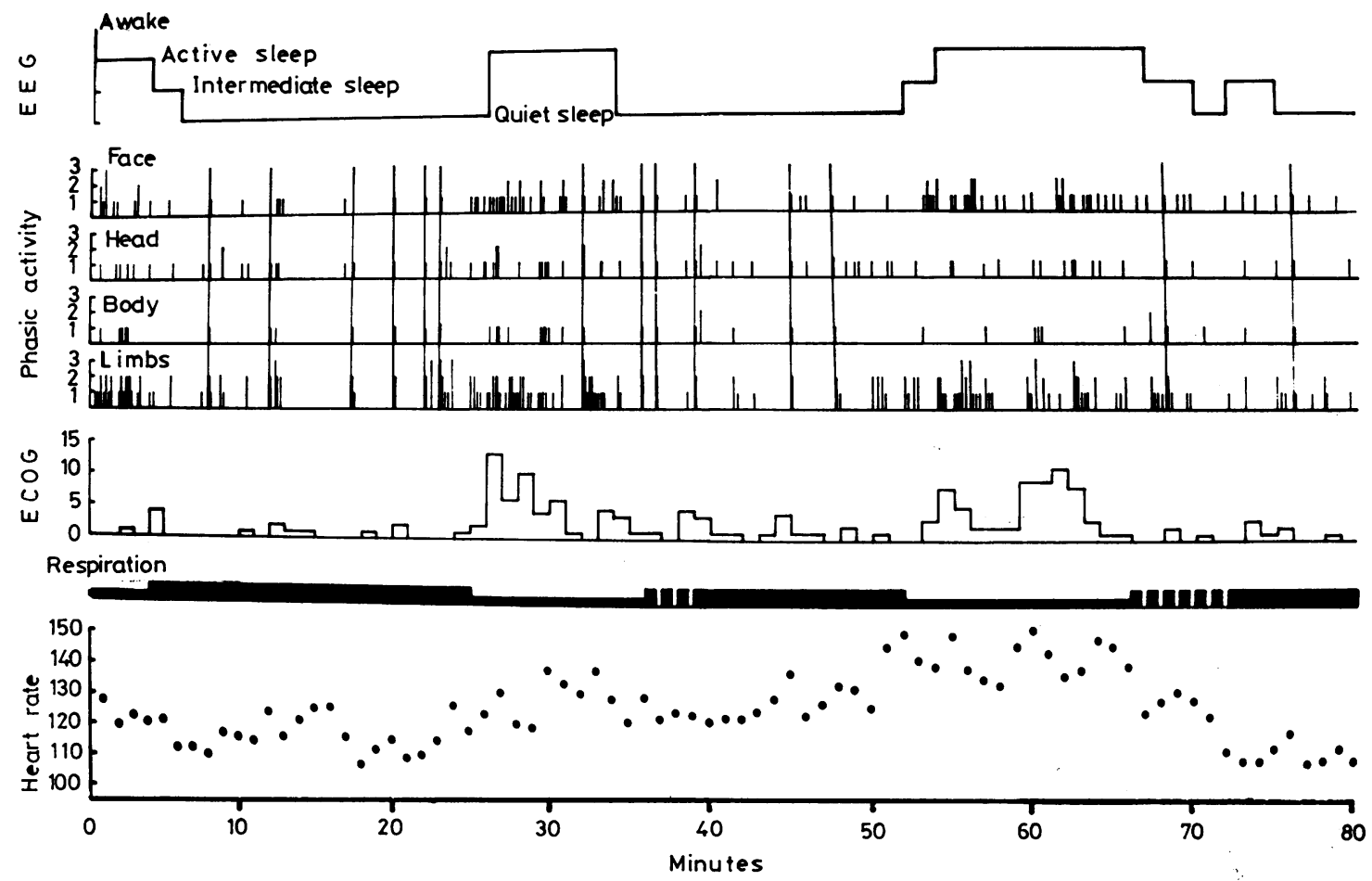

Fig. 1 Undernourished group of newborn babies, showing shortened and disorganised sleep cycle with frequent ocular movements and phasic activity. Heart rate is irregular. Vertical lines across phasic activity denote 'startles'. 

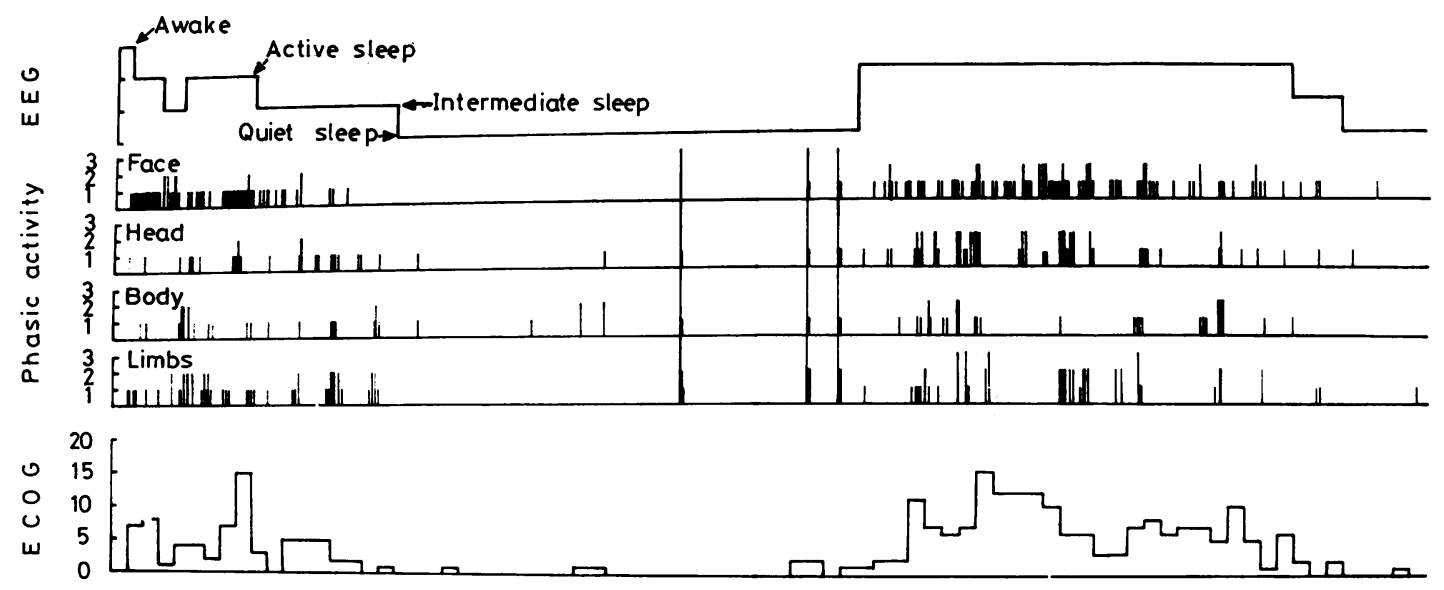

Respiration

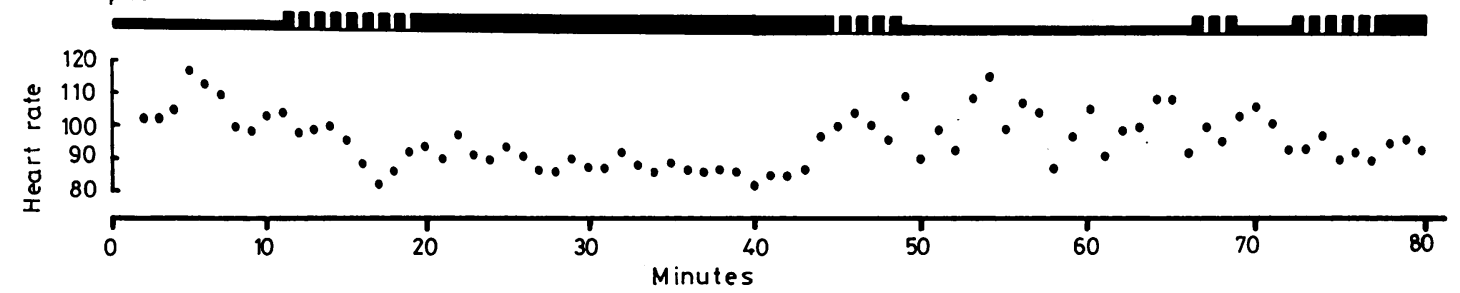

Fig. 2 Control group of newborn babies showing organisation of parameters.

intrauterine growth retardation, the mean weight with standard error being $2007.97 \pm 9.09 \mathrm{~g}$ compared with $3178 \cdot 47 \pm 78 \cdot 18 \mathrm{~g}$ in the control group. The placental weight was reduced in proportion to the baby's weight, demonstrating a direct correlation, the value of ' $r$ ' being +0.45 and +0.47 for the undernourished and control groups respectively. These correlation coefficients were significant $(P<0.05$; Table 1$)$.

The graphic presentation of the sleep cycle showed that the organisation of the various parameters (EEG, respiration, heart rate, body activity, and ocular movements) during sleep was poor in most of the babies born to undernourished mothers (Fig. 1), while babies in the control group showed a

Table 1 Placental weight, protein content, and mean birthweight in control and undernourished groups $($ mean $\pm S E)$

\begin{tabular}{|c|c|c|}
\hline & $\begin{array}{l}\text { Control group } \\
(n=19)\end{array}$ & $\begin{array}{l}\text { Undernourished babies } \\
(n=19)\end{array}$ \\
\hline $\begin{array}{l}\text { Placental weight (g) } \\
\text { Placental protein } \\
\text { content (mg/g wet } \\
\text { tissue) } \\
\text { Birthweight (g) }\end{array}$ & $\begin{array}{c}449.2 \pm 13.03 \\
63 \cdot 74 \pm 0 \cdot 54 \\
3178 \cdot 47 \pm 78 \cdot 18\end{array}$ & $\begin{array}{c}285.4 \pm 12.91^{* * *} \\
57.0 \pm 1 \cdot 12^{* * *} \\
2007.97 \pm 9.09^{* * *}\end{array}$ \\
\hline
\end{tabular}

fairly good degree of organisation for these parameters (Fig. 2). The disorganisation in the former group occurred mainly during quiet NREM sleep when frequent body movements were registered, the heart rate was often irregular, and there were many ocular movements. This disorganisation led to a significantly increased amount of intermediate sleep compared with the controls $(P<0.01$; Table 2$)$.

Normal newborn babies showed reduction of heart rate during quiet NREM sleep by $7.9 \pm 1.09$ beats/minute compared with active REM sleep, but this reduction was less evident in the undernourished group $(4.85 \pm 0.93, P<0.05)$. Ocular movements and their variations during active REM and quiet NREM sleep were found to be similar in both groups (Table 3).

The mean durations of the total cycle, quiet sleep,

Table 2 Percentage distribution of active, quiet, and intermediate sleep in babies born to control and undernourished mothers (mean $\pm S E$ )

\begin{tabular}{lll}
\hline Sleep state & $\begin{array}{l}\text { Control group } \\
(n=19)\end{array}$ & $\begin{array}{l}\text { Undernourished babies } \\
(n=19)\end{array}$ \\
\hline Active & $44 \cdot 1 \pm 2 \cdot 21$ & $39 \cdot 7 \pm 2 \cdot 38$ \\
Quiet & $38 \cdot 3 \pm 1 \cdot 70$ & $34 \cdot 5 \pm 2 \cdot 61$ \\
Intermediate & $17.6 \pm 1.67$ & $25 \cdot 8 \pm 1 \cdot 74^{* *}$ \\
\hline
\end{tabular}


Table 3 Heart rate, ocular movements, and percentage differences in the two sleep states (mean $\pm S E$ )

\begin{tabular}{|c|c|c|c|}
\hline Group & Active sleep & Quiet sleep & Differenco \\
\hline $\begin{array}{l}\text { Heart rate/min } \\
\text { Control } \\
\text { Undernourished }\end{array}$ & $\begin{array}{l}121 \cdot 5 \pm 3 \cdot 23 \\
126 \cdot 0 \pm 2 \cdot 85\end{array}$ & $\begin{array}{l}113 \cdot 6 \pm 3 \cdot 61 \\
121 \cdot 2 \pm 4 \cdot 23\end{array}$ & $\begin{array}{l}7.9 \pm 1.09 \\
4.8 \pm 0.93^{*}\end{array}$ \\
\hline $\begin{array}{l}\text { Ocular movement } \\
\text { Control } \\
\text { Undernourished }\end{array}$ & $\begin{array}{l}6.8 \pm 2 \cdot 80 \\
6.5 \pm 4 \cdot 21\end{array}$ & $\begin{array}{l}0.97 \pm 0.57 \\
0.83 \pm 0.22\end{array}$ & $\begin{array}{l}5.9 \pm 0.49 \\
5.7 \pm 0.92\end{array}$ \\
\hline
\end{tabular}

Table 4 Duration of total sleep cycle, active, and quiet sleep in babies born to control and undernourished mothers (mean $\pm S E$ )

\begin{tabular}{lll}
\hline Sleep cycle/min & $\begin{array}{l}\text { Control group } \\
(n=19)\end{array}$ & $\begin{array}{l}\text { Undernourished babies } \\
(n=19)\end{array}$ \\
\hline Total cycle & $51 \cdot 6 \pm 1 \cdot 36$ & $41 \cdot 6 \pm 1 \cdot 81^{* * *}$ \\
Active sleep & $26.9 \pm 1 \cdot 29$ & $20 \cdot 4 \pm 1 \cdot 28^{* * *}$ \\
Quiet sleep & $24 \cdot 7 \pm 0.75$ & $21 \cdot 3 \pm 0 \cdot 84^{* *}$ \\
\hline
\end{tabular}

$* * \mathrm{P}<0.01, * * * \mathrm{P}<0.001$.

Table 5 Distribution of sleep cycle/min according to birthweight (mean $\pm S E$ )

\begin{tabular}{|c|c|c|c|}
\hline Birthweight (g) & $\begin{array}{l}\text { Total cycle } \\
\text { (min) }\end{array}$ & $\begin{array}{l}\text { Active sleep } \\
\text { (min) }\end{array}$ & $\begin{array}{l}\text { Quiet sleep } \\
\text { (min) }\end{array}$ \\
\hline $\begin{array}{l}>2500(\text { mean, } \\
3178 \cdot 5)(n=19) \\
2500-2000\end{array}$ & $51 \cdot 6 \pm 1 \cdot 36$ & $26 \cdot 9 \pm 1 \cdot 29$ & $24.7 \pm 0.75$ \\
\hline $\begin{aligned} & (\text { mean, 2146) }(n=9) \\
<2000 & (\text { mean, 1870) }(n=10)\end{aligned}$ & $\begin{array}{l}44 \cdot 3 \pm 1 \cdot 85 \\
t=3 \cdot 15^{* *} \\
40 \cdot 2 \pm 2 \cdot 64 \\
t=3 \cdot 85^{* * *}\end{array}$ & $\begin{array}{l}22 \cdot 3 \pm 1 \cdot 89 \\
t=2 \cdot 0^{*} \\
18 \cdot 3 \pm 1 \cdot 60 \\
t=3 \cdot 99^{* * *}\end{array}$ & $\begin{array}{l}21 \cdot 0 \pm 1 \cdot 07 \\
t=2 \cdot 7^{* *} \\
21 \cdot 5 \pm 1 \cdot 32 \\
t=2 \cdot 14^{*}\end{array}$ \\
\hline
\end{tabular}

$* P<0.5,{ }^{* *} P<0.01, * * * P<0.001$.

and active sleep are shown in Table 4. The duration of the total sleep cycle was significantly shorter in babies born to undernourished mothers $(41 \cdot 6 \pm$ $1 \cdot 81 \mathrm{~min})$ compared with the control group (51.6 \pm $1.36 \mathrm{~min})$. The values for active REM and quiet NREM sleep of the control group were $26 \cdot 9 \pm 1 \cdot 29$ and $24.7 \pm 0.75 \mathrm{~min}$ respectively. The corresponding values for the undernourished group were $20 \cdot 4 \pm 1 \cdot 28$ and $21 \cdot 3 \pm 0.84 \mathrm{~min}$ respectively. Both differences were highly significant.

The sleep cycle in the babies of birthweights between 2000 and $2500 \mathrm{~g}$ (mean 2146) resembled that of babies weighing under $2000 \mathrm{~g}$ (mean 1870). In the latter group, duration of active sleep was further reduced while quiet sleep remained unaltered. The difference was however, not significant $(\mathbf{P}<\mathbf{0} \cdot 1$; Table 5).

In several EEG recordings of the babies in the undernourished group there was pronounced inter- and intrahemispheric asymmetry and abnormal paroxysmal discharges were recorded. It was still possible to identify the sleep cycle in such records.

\section{Discussion}

The values of duration of the total sleep cycle, active sleep, and quiet sleep of the control group in the present study were similar to those of Roffwarg et al. ${ }^{9}$ and Stern et al. ${ }^{12}$ who reported the duration of the total sleep cycle as $43 \cdot 4-61 \cdot 2$, and $47 \cdot 0$ minutes respectively. Similarly the content of active REM sleep has been reported to vary from $40 \%{ }^{13}$ to $50 \%{ }^{914-15}$ Parmelee et al..$^{10}$ reported the mean percentage of active sleep to be about $49 \%$ and quiet sleep about $34 \%$; the rest they designated as transitional sleep.

The babies of undernourished mothers in the present study demonstrated (1) shortening of sleep cycle; (2) reduced duration of both active REM and quiet NREM sleep, and a still greater reduction in duration of active REM sleep for babies weighing $<2000 \mathrm{~g}$; (3) generalised disorganisation of sleep, leading to significantly increased content of intermediate sleep, and (4) in some, inter- and intrahemispheric asymmetry and abnormal paroxysmal discharges.

In term babies of mothers addicted to heroin and in infants at risk for CNS impairment, Schul$\operatorname{man}^{16}$ showed that there was excessive activity during active REM sleep and he failed to exhibit any well organised quiet NREM sleep. Immature sleep patterns have been reported in small-for-date babies of toxaemic mothers by Schulte et al. ${ }^{17}$ Such changes suggest generalised dysmaturation of the developing brain; they may even indicate brain damage due to varied intrauterine insults.

The evident physiological changes in the sleep polygrams indicate pathological deviations and maturational lags in development due to intrauterine insult. Although no comparable study so far has been reported in babies born to undernourished mothers, it seems likely that intrauterine nutritional deprivation is responsible for these changes. Recent studies show that REM and NREM sleep are controlled by anatomically distinct monoaminergic systems. 5-Hydroxytryptamine (5-HT) containing neurones in the midline pontomedullary raphe nuclei initiate quiet NREM sleep, whereas noradrenaline-containing neurones in the locus ceruleus modulate active REM sleep. ${ }^{18}$ Shoemaker and Wurtman ${ }^{3}$ and Im et al. ${ }^{4}$ found reduced synthesis of noradrenaline and 5-HT, and raised cholinesterase activity in whole brain of rats subjected to early undernutrition. Studies have shown that reduction of both 5-HT and acetylcholine reduces the duration and induction of total and paradoxical sleep. ${ }^{18-20}$ It is difficult to assess whether the reduction of these neurohumoral agents in the total brain is reflected in sleep regulating centre(s). 
Disorganisation of the sleep cycle and the reduction in REM sleep content may be important in the development of intellectual and neurointegrative functions of the infant. REM sleep is considered to be ontogenetically primitive, and constitutes the major proportion of sleep in preterm and term infants. ${ }^{912} 21$ It offers intense stimulation to the CNS, considered to be essential to the developing brain in utero, and later in early extrauterine life when external stimuli are limited. ${ }^{9}$ The percentage of REM sleep may decrease owing to environmental deprivation ${ }^{22}$ or it may increase after a period of intense learning. ${ }^{23}$ REM sleep deprivation may lead to poor acquisition or retention of several kinds of learning. ${ }^{12}$ These studies are particularly relevant since severe intellectual and neuromotor deficits have been noticed in babies of low birthweights. ${ }^{24}$

\section{References}

1 Platt B S, Heard C R C, Stewart R J C. Experimental protein calorie deficiency. In: Munro $\mathbf{H} \mathbf{N}$, Allison $\mathbf{J}$ B, eds. Mammalian protein metabolism, vol. 2. New York: Academic Press, 1964; 446-521.

2 Fish I, Winick M. Effect of malnutrition on regional growth of developing rat brain. Exp Neurol 1969; 25: $534-40$.

3 Shoemaker S W J, Wurtman R J. Perinatal undernutrition: accumulation of catecholamines in rat brains. Science 1971; 171: 1017-19.

4 Im H S, Barnes R H, Levitsky D, Krook L, Pond W G. Postnatal malnutrition and regional cholinestrase activity in brain of pigs (abstract). Fed Proc 1972; 31 : 697.

5 Katiyar G P, Agarwal K N, Shanker R, Nagchaudhuri J. Effect of protein energy deprivation on the brain enzymes of glutamic acid in preweanling rats. Nutr Metab 1976; 20: $396-403$.

- Dobbing J, Smart J L. Vulnerability of developing brain and behaviour. Br Med Bull 1974; 30: 164-8.

7 Ellingson R J, Lindsley D B. Brain waves and cortical development in newborn and young infants. Am Psychol $1964 ; 4: 248-9$.

8 Dreyfus-Brisac C. The electroencephalogram of premature infant and full term infant: normal and abnormal development of waking and sleeping patterns. In: Kellaway P C, Peterson K G I, eds. Neurological and electroencephalographic studies in infancy. New York: Grune \& Stratton, 1964: 186-207.

- Roffwarg H P, Muzio J N, Dement W C. Ontogenetic development of the human sleep-dream cycle. Science, 1966; 152: 604-19.

10 Parmelee A H, Jr, Schulte F J, Akiyama Y, Wenner W H,
Shultz M A, Stern E. Maturation on EEG activity during sleep in premature infants. Electroencephalogr Clin Neurophysiol 1968; 24: 319-29.

11 Lowry O H, Rosenbrough N J, Farr A L, Randall R J. Protein measurement with the folin phenol reagent. J Biol Chem 1951; 193: 265-75.

12 Stern E, Parmelee A H, Jr, Akiyama Y, Schultz M A, Wenner W H. Sleep cycle characteristics in infants. Pediatrics 1969; 43: 65-70.

13 Petre-Quadens $O$. On the different phases of the sleep of the newborn with special reference to the activated phase or phase d. J Neurol Sci 1966; 3: 151-61.

14 Dreyfus-Brisac C, Monod N. Sleep of premature and full terms. Polygraphic study. Proc $R$ Soc Med 1965; 58: 6-7.

15 Monod N, Pajot N. Le sommeil du nouveau-né et du prématuré. I. Analyse des études polygraphiques (mouvements oculaires, respiration, et EEG) chez le nouveau-né à terme. Biol Neonate $1965 ; 8$ : 281-307.

16 Schulman C. Alterations of sleep cycle in heroin-addicted and 'suspected' newborns. Neuropaediatrie 1969; 1 : 8993.

17 Schulte F J, Hinze G, Schrempf G. Maternal toxemia, fetal malnutrition, and bioelectric brain activity of the newborn. Neuropaediatrie 1971; 2: 439-60.

18 Jouvet $M$. Some monoaminergic mechanisms controling sleep and waking. In: Karczmar A G, Eccles J C, eds. Proceedings of a Symposium on the brain and human behavior, Logola University, Chicago, 1969. Berlin: Springer, 1972: 131-61.

19 George R, Heslett W L, Jenden D J. A cholenergic mechanism in the brain stem reticular formation: induction of paradoxical sleep. Neuropharmacology 1964; 3: 451-2.

20 Baxter B L. Induction of both emotional behaviour and a novel form of REM-sleep by chemical stimulation applied to cat mesencephalon. Exp Neurol 1969; 23: 220-9.

21 Parmelee A H, Jr, Wenner W H, Akiyama Y, Flescher J. Electroencephalographic and brain maturation. In: Minkowski A, ed. Regional development of the brain in early life. Oxford: Blackwell, 1967: 459-76.

22 McGuity D J. Effect of prolonged isolation and subsequent enrichment on sleep pattern in kittens (abstract). Electroencephalogr Clin Neurophysiol 1969; 26: 335.

23 Lucero M A. Lengthening of REM sleep duration consecutive to learning in the rat. Brain Res 1970; 20: 319-22.

24 Fitzhardinge $\mathbf{P}$ M, Steven $A$ M. The small for dates infants. Neurological and intellectual sequelae. Pediatrics 1972; 50: 50-7.

Correspondence to Professor K N Agarwal, Department of Paediatrics, Institute of Medical Sciences, Banaras Hindu University, Varanasi 221005, India.

Received 6 February 1979 